\title{
CCN3 (NOV) Drives Degradative Changes in Aging Articular Cartilage
}

\author{
Miho Kuwahara ${ }^{1,2}$, Koichi Kadoya ${ }^{3}$, Sei Kondo ${ }^{1}$, Shanqi Fu ${ }^{1}$, Yoshiko Miyake ${ }^{1}$, Ayako Ogo ${ }^{1}$, \\ Mitsuaki Ono ${ }^{4}$, Takayuki Furumatsu ${ }^{5}$, Eiji Nakata ${ }^{5}$, Takako Sasaki ${ }^{6}$, Shogo Minagi ${ }^{2}$, \\ Masaharu Takigawa ${ }^{7}$, Satoshi Kubota ${ }^{1}$ and Takako Hattori ${ }^{1}, *$ (D)
}

1 Department of Biochemistry and Molecular Dentistry, Okayama University Graduate School of Medicine, Dentistry and Pharmaceutical Sciences, Okayama 700-8525, Japan;

kuwahara.miho@s.okayama-u.ac.jp (M.K.); de421016@s.okayama-u.ac.jp (S.K.);

fushanqi@s.okayama-u.ac.jp (S.F.); yoshiko-m@okayama-u.ac.jp (Y.M.); carinablue2004@yahoo.co.jp (A.O.);

kubota1@md.okayama-u.ac.jp (S.K.)

2 Department of Occlusal and Oral Functional Rehabilitation, Okayama University Graduate School of Medicine, Dentistry and Pharmaceutical Sciences, Okayama 700-8525, Japan; minagi@md.okayama-u.ac.jp

3 Department of Oral and Maxillofacial Surgery, Okayama University Graduate School of Medicine, Dentistry and Pharmaceutical Sciences, Okayama 700-8525, Japan; de422015@s.okayama-u.ac.jp

4 Department of Molecular Biology and Biochemistry, Okayama University Graduate School of Medicine, Dentistry and Pharmaceutical Sciences, Okayama 700-8525, Japan; mitsuaki@md.okayama-u.ac.jp

5 Department of Orthopedic Surgery, Okayama University Graduate School of Medicine, Dentistry and Pharmaceutical Sciences, Okayama 700-8525, Japan; matino@md.okayama-u.ac.jp (T.F.); eijinakata8522@yahoo.co.jp (E.N.)

6 Department of Biochemistry, Faculty of Medicine, Oita University, Oita 879-5593, Japan; tsasaki@oita-u.ac.jp

7 Advanced Research Center for Oral and Craniofacial Sciences, Okayama University Dental School/Graduate School of Medicine, Dentistry and Pharmaceutical Sciences, Okayama 700-8525, Japan; takigawa@md.okayama-u.ac.jp

* Correspondence: hattorit@md.okayama-u.ac.jp; Tel./Fax: +81-862-356-646

Received: 4 September 2020; Accepted: 8 October 2020; Published: 13 October 2020

check for updates

\begin{abstract}
Aging is a major risk factor of osteoarthritis, which is characterized by the degeneration of articular cartilage. $\mathrm{CCN} 3$, a member of the $\mathrm{CCN}$ family, is expressed in cartilage and has various physiological functions during chondrocyte development, differentiation, and regeneration. Here, we examine the role of $\mathrm{CCN} 3$ in cartilage maintenance. During aging, the expression of $\mathrm{Ccn} 3 \mathrm{mRNA}$ in mouse primary chondrocytes from knee cartilage increased and showed a positive correlation with $p 21$ and $p 53$ mRNA. Increased accumulation of CCN3 protein was confirmed. To analyze the effects of CCN3 in vitro, either primary cultured human articular chondrocytes or rat chondrosarcoma cell line (RCS) were used. Artificial senescence induced by $\mathrm{H}_{2} \mathrm{O}_{2}$ caused a dose-dependent increase in $\mathrm{C} n 3$ gene and CCN3 protein expression, along with enhanced expression of $p 21$ and $p 53$ mRNA and proteins, as well as SA- $\beta$ gal activity. Overexpression of $\mathrm{CCN} 3$ also enhanced $p 21$ promoter activity via $p 53$. Accordingly, the addition of recombinant $\mathrm{CCN} 3$ protein to the culture increased the expression of $p 21$ and $p 53$ mRNAs. We have produced cartilage-specific CCN3-overexpressing transgenic mice, and found degradative changes in knee joints within two months. Inflammatory gene expression was found even in the rib chondrocytes of three-month-old transgenic mice. Similar results were observed in human knee articular chondrocytes from patients at both mRNA and protein levels. These results indicate that $\mathrm{CCN} 3$ is a new senescence marker of chondrocytes, and the overexpression of CCN3 in cartilage may in part promote chondrocyte senescence, leading to the degeneration of articular cartilage through the induction of p53 and p21.
\end{abstract}


Keywords: cellular communication network factor 3; CCN3; NOV; primary chondrocytes; aging; oxidative stress; senescence; p21; p53; SASP

\section{Introduction}

Aging is a main risk factor of senescence, which involves a decrease in biological functions such as muscle strength, nerve conduction velocity, vital capacity, and resistance to illness. In terms of cartilage, aging increases the risk of osteoarthritis (OA), which is the most common joint disease characterized by articular cartilage degeneration, and causes severe joint pain, physical disability, and impairment of quality of life. Despite recent advances in our knowledge of disease pathogenesis, treatment is still a challenge and, unlike for inflammatory joint diseases, no disease-modifying drugs are currently available for OA [1]. Although OA is not an inevitable consequence of senescence, aging is a strong risk factor for OA [2]. Chondrocytes undergo age-dependent senescence, which is characterized by a decline in the proliferative and synthetic capacity of cellular products, including their extracellular matrices; this is considered to play a significant role in the pathology of OA [3]. Although aging and OA are closely linked, they are independent processes. Several reports show the mechanism of contribution of aging to OA: age-related inflammation [4], cellular senescence (including the senescence-associated secretory phenotype (SASP)) [5-7], mitochondrial dysfunction and oxidative stress [8-10], and dysfunction in energy metabolism. This metabolic dysfunction is due to the reduced activity of 5'-AMP-activated protein kinase (AMPK) [11-13], which is associated with reduced autophagy. Alterations in cell signaling due to age-related changes in the extracellular matrix [14] are also of note. Improved understanding of the aging-related mechanisms that promote OA could lead to the discovery of new targets for therapies that aim to slow or stop the progression of this chronic and disabling disease.

Cellular communication network factor 3 (CCN3), previously called nephroblastoma overexpressed (NOV), is a secreted multifunctional protein involved in a variety of cellular processes, and interacts with various extracellular and transmembrane proteins [15-17]. Our previous studies have shown that $\mathrm{CCN} 3$ suppresses the proliferation and maturation of growth plate chondrocytes, regulating the expression of chondrocytic extracellular matrix (ECM) genes and Sox9 [18]. In the present study, we show for the first time that the expression of CCN3 is elevated in aging mouse and human articular cartilage. Cell cycle arrest by $\mathrm{H}_{2} \mathrm{O}_{2}$ demonstrated induction of $\mathrm{Ccn} 3$ as well as Col10a1 and matrix metalloproteinases mRNA, and downregulation of Col2a1 mRNA. The overexpression of CCN3 induced promoter activity of $p 21$, which has multiple $p 53$-responsive elements. An in vivo mouse model of CCN3 overexpression in cartilage showed prominent degenerative changes in articular cartilage. Here, we propose that CCN3 is a novel senescence marker of chondrocytes, and overexpression of CCN3 in cartilage can be one of the factors that partly promotes chondrocyte senescence and degeneration of articular cartilage via p53 and p21.

\section{Results}

\subsection{Increased Expression and Accumulation of CCN3 in Mouse Articular Cartilage with Aging}

First, we examined the expression level of $C \mathrm{cn} 3 \mathrm{mRNA}$ in primary mouse chondrocytes from embryonic 18.5-day rib cage cartilage and postnatal two days to 37-weeks-old knee joints by quantitative RT-PCR standardized by either glyceraldehyde 3-phosphate dehydrogenase (Gapdh) mRNA, total RNA amount, or transmembrane protein 199 (Tmem199) mRNA. Since for Gapdh, a housekeeping gene, mRNA expression decreased with age (Supplemental Figure S1a), Tmem199, a gene reported to undergo little fluctuation in gene expression during aging [19], was also used for the normalization of Ccn3 mRNA (Supplemental Figure S1b). A strong positive correlation was observed between age and Ccn3 expression level, standardized by either Gapdh mRNA, total RNA amount, or Tmem199 mRNA 
(Spearman's rank correlation coefficient (rs): 0.77 for Ccn3/Gapdh, 0.77 for Ccn3/Tmem199, and 0.97 for

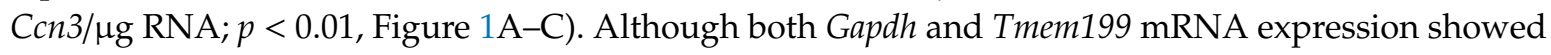
negative correlation with age, altogether these results indicated a strong positive correlation of $\mathrm{CCN} 3$ expression with age in chondrocytes. For better comparison, expression of all other genes was hence standardized to Gapdh.
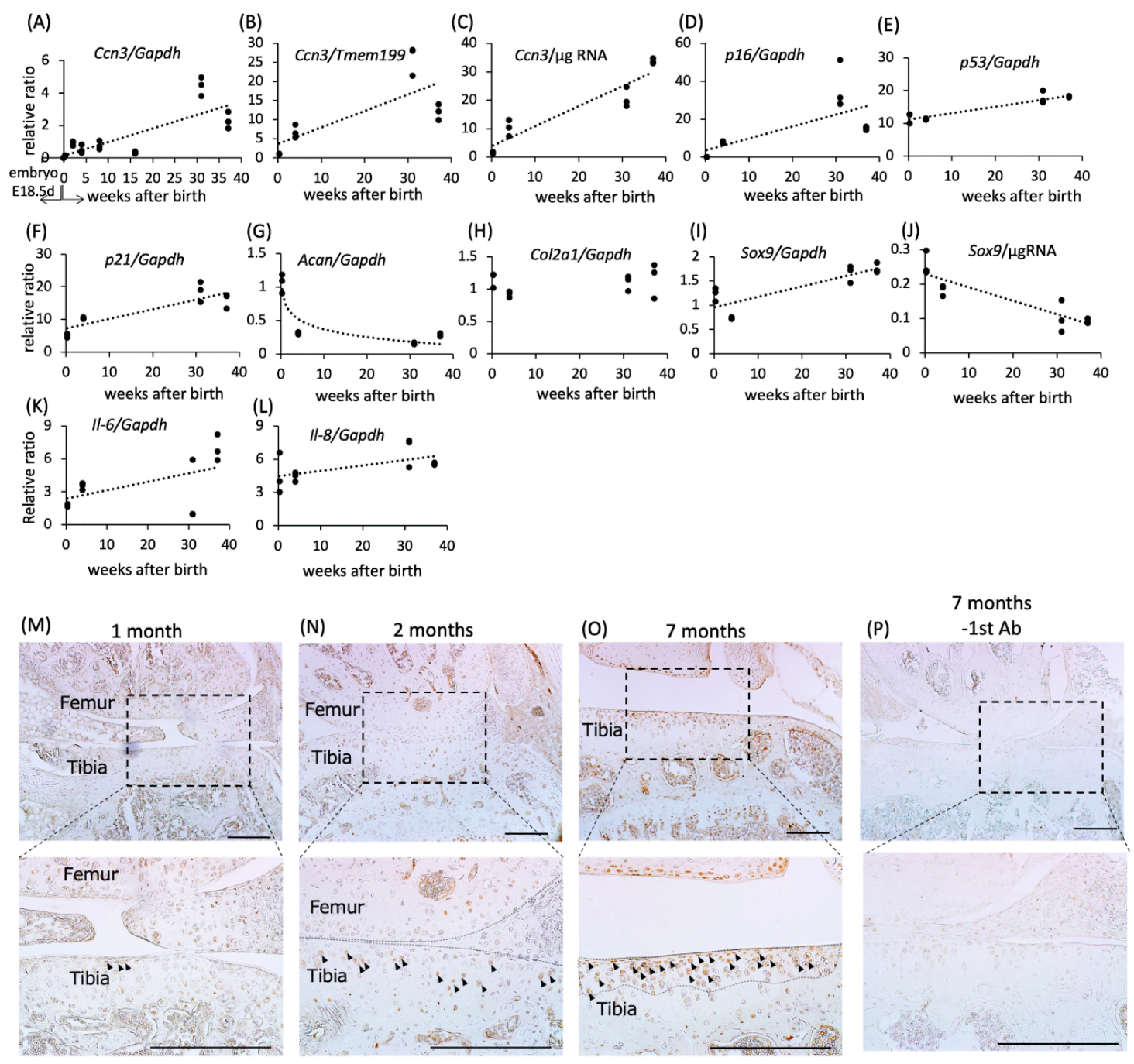

Figure 1. Comparison of mRNA expression levels of (A-C) Ccn3, (D) $p 16$, (E) $p 53,(\mathbf{F}) p 21,(\mathbf{G})$ Acan, (H) Col2a1, (I,J) Sox9, (K) Il-6, and (L) Il-8 in articular chondrocytes of different ages (embryo E18.5 represents RNA from ribcage chondrocytes of embryonic day 18.5). The expression level of Ccn3 mRNA was standardized with (A) Gapdh, (B) Tmem199, a gene with little fluctuation in expression during aging, and (C) RNA amount. The expression level of Acan mRNA dramatically decreased with age, but Col2a1 mRNA expression did not. Sox 9 mRNA expression increased when it was standardized by Gapdh; however, the expression level/ $\mu$ g RNA decreased with age. (K,L) Il-6 and $\mathrm{Il}-8$, as senescence-associated secretory phenotype (SASP) factors, also showed increased expression with age $(p<0.05)$. Either rib cage (E.18.5) or knee articular (postnatal) cartilage was pooled from 8 embryos or 4 postnatal animals and seeded into at least 3 dishes. RNA from each dish was analyzed with triplicate by real time PCR, and the average of the value from one RNA sample was plotted as one 'dot'. (M-P) Immunohistochemical staining of CCN3 in one-, two-, and seven-month old mouse articular cartilage. CCN3-positive chondrocytes (arrow) increased in the superficial layer of articular cartilage (dotted circle) of seven-month-old compared with one-month-old mice. No signal was observed without CCN3-specific antibody (Figure 1P, -1st Ab). Scale bar: $200 \mu \mathrm{m}$. 
To determine whether murine chondrocytes display characteristic features of senescent cells with age, we assessed the expression of genes that arrest cell cycle, such as $p 16, p 53$, and $p 21$. As shown in Figure 1D-F, the expression of these genes was positively correlated with age ( $r s: 0.77$ for $p 16 / G a p d h$, 0.77 for $p 53 /$ Gapdh, and 0.82 for $p 21 /$ Gapdh; $p<0.01$ ).

Expression levels of chondrocyte marker genes were also assessed: Aggrecan and type 2 collagen are the major and cartilage-specific components of the extracellular matrix. Postnatal expression of Aggrecan (Acan) mRNA dropped dramatically ( $r s:-0.73$ for Acan/Gapdh, $p<0.01$ ), while no significant age-related changes in Col2a1 expression were observed (Figure 1G,H) in this period. The expression of Sox9, a transcription factor for cartilage differentiation, standardized by Gapdh mRNA increased with age ( $r s: 0.69$ for Sox9/Gapdh, $p<0.01$ ), but decreased when standardized to RNA ( $r s$ : -0.88 for So $x 9 / \mu$ R RA, $p<0.01$, Figure 1I,J; see discussion). Senescence-associated secretory phenotype (SASP) -related inflammatory factors such as Il-6 or Il-8 were elevated with age ( $r s: 0.5670076$ for Il-6/Gapdh, and 0.5182002 for $I l-8 / G a p d h ; p<0.05$, Figure $1 \mathrm{~K}, \mathrm{~L}$ ). Accumulation of CCN3 protein was observed by immunohistochemical staining of CCN3 in knee joint cartilage from one-, two-, and seven-month-old mice. The number of CCN3-positive chondrocytes increased in the superficial zone of seven-month-old articular cartilage (Figure 1M-O). No positive staining was observed without CCN3-specific antibody (Figure 1P).

\subsection{Increased Expression of $\mathrm{CCN} 3$ in $\mathrm{H}_{2} \mathrm{O}_{2}$-Treated Chondrocytes}

To induce cellular senescence by oxidative stress in vitro, human primary articular chondrocytes from 48 years old patient (Figure 2A) and rat chondrosarcoma-derived cells (RCS, Figure 2B) were exposed to $\mathrm{H}_{2} \mathrm{O}_{2}$ at various concentrations for $2 \mathrm{~h}$, and the medium was changed to a normal growing medium, followed by $24 \mathrm{~h}$ incubation. Thereafter, total RNA was extracted and subjected to RT-qPCR analysis.

In human primary chondrocytes, CCN3 mRNA expression increased significantly by $\mathrm{H}_{2} \mathrm{O}_{2}$ treatment in a dose-dependent manner (Figure $2 \mathrm{~A},{ }^{*} p<0.05$ ). The expression of $p 21$ and $p 53 \mathrm{mRNAs}$ was also significantly induced by $\mathrm{H}_{2} \mathrm{O}_{2}$ in a dose-dependent manner (Figure $2 \mathrm{~A},{ }^{*} p<0.05$ ), indicating cell cycle was arrested in $\mathrm{H}_{2} \mathrm{O}_{2}$-treated articular chondrocytes. Col2a1 mRNA was increased at relatively lower concentration of $\mathrm{H}_{2} \mathrm{O}_{2}$ but increased concentration of $\mathrm{H}_{2} \mathrm{O}_{2}$ repressed the expression, indicating that an escaping system exists from oxidative stress. Acan mRNA was reduced dose dependently. Expression of COL10A1 and MMP13 by $\mathrm{H}_{2} \mathrm{O}_{2}$ was slightly induced, but it was not significant (Figure 2A).

Similarly, in RCS cells, elevated expression of Ccn3, p21, and $p 53$ mRNA was observed. Col2a1 and Acan mRNA were also reduced in a relatively higher concentration of $\mathrm{H}_{2} \mathrm{O}_{2}$, however, rather lower concentration of $\mathrm{H}_{2} \mathrm{O}_{2}$ increased the expression in RCS cells. Mmp13 and Adamts5 encoding matrix metalloproteinases, which specifically degrade cartilaginous matrices, and Col10a1, a marker of hypertrophic cartilage, which is induced during osteophyte formation, were significantly induced by treatment with $\mathrm{H}_{2} \mathrm{O}_{2}$ in RCS cells (Figure $2 \mathrm{~B}$, ${ }^{*} p<0.05$ ), however, at highest concentration of $\mathrm{H}_{2} \mathrm{O}_{2}$, $M m p 13$ mRNA was reduced, indicating that the maximum concentration of $\mathrm{H}_{2} \mathrm{O}_{2}$ to induce $M m p 13$ was lower than that for Col10A1 or Adamts5 mRNA in RCS cells. 
(A)
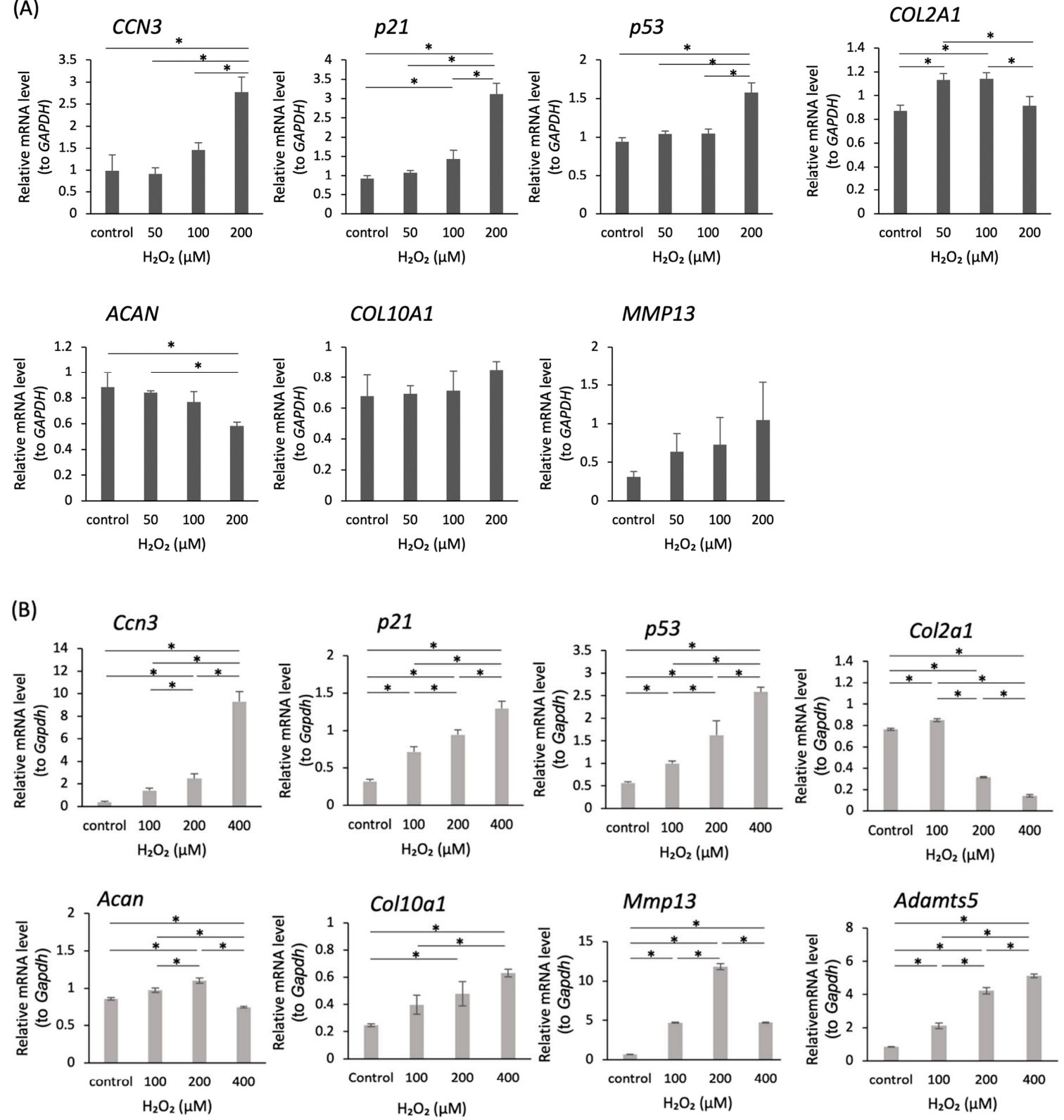

(C)
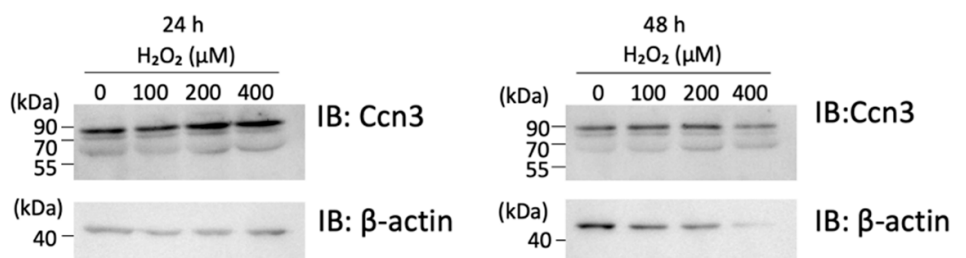

Figure 2. Cont. 
(D)

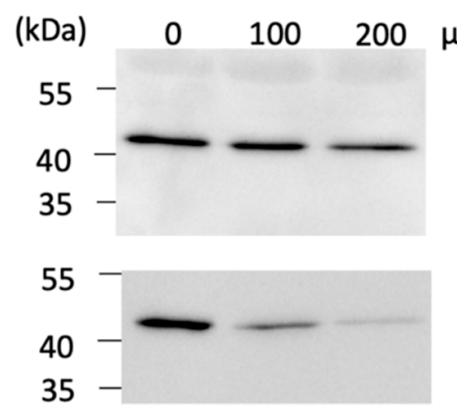

$\mu \mathrm{M}$

IB: p53

IB: ßactin
p53/Bactin

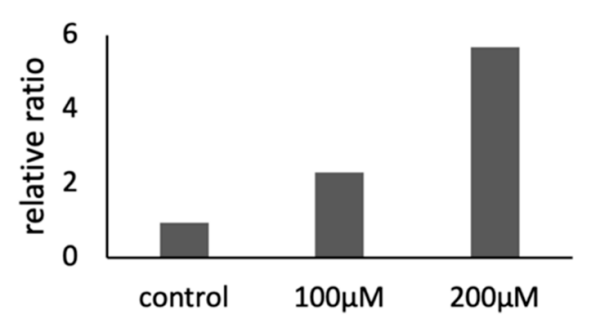

(E)

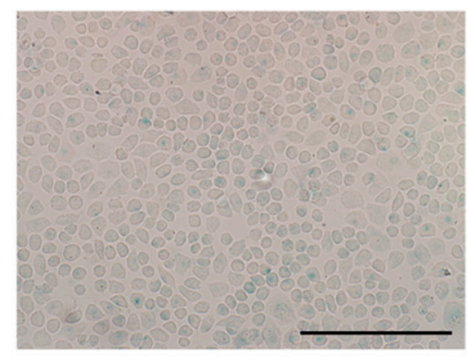

$100 \mu \mathrm{M}$

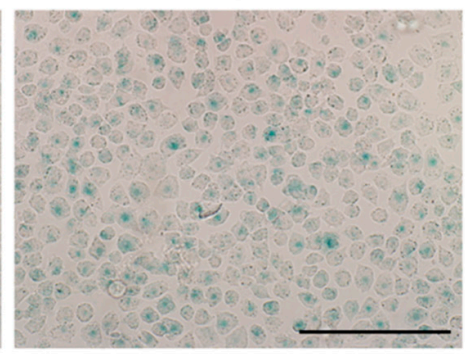

$200 \mu \mathrm{M}$

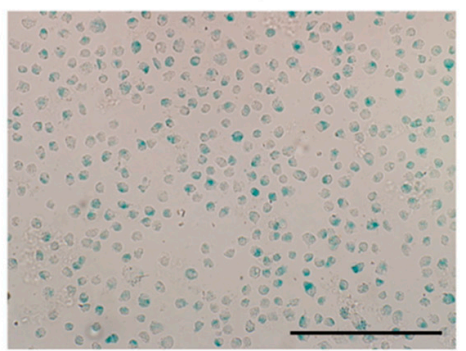

Figure 2. Increased expression of $\mathrm{Ccn} 3 \mathrm{mRNA}$ and protein in $\mathrm{H}_{2} \mathrm{O}_{2}$-treated chondrocytes. (A) Human primary articular chondrocytes isolated from 48 years old patient and (B) RCS cells were treated with increased concentration of $\mathrm{H}_{2} \mathrm{O}_{2}$ as indicated for $2 \mathrm{~h}$ to induce artificial senescence by oxidative stress, followed by changing to the normal growing media without $\mathrm{H}_{2} \mathrm{O}_{2}$. Total RNA was collected $24 \mathrm{~h}$ after changing media, and (A) CCN3, p21, p53, COL2A1, ACAN, COL10A1, MMP13 mRNA, and (B) Ccn3, p21, p53, Col2a1, Acan, Col10a1, Mmp13, and Adamts5 mRNA levels were monitored and standardized with Gapdh. The data represent the mean \pm SD ( $n=3$ individual cultures); ${ }^{*} p \leq 0.05$. (C) Cell lysates were collected both 24 and $48 \mathrm{~h}$ after changing media and CCN3 protein level was monitored with an anti-CCN3 antibody. (D, left) Cell lysates were collected $48 \mathrm{~h}$ after changing media and p53 protein level was monitored with an anti-p53 antibody. (D, right) Band intensity of p53 was standardized to $\beta$ actin. (E) Colorimetric detection of senescence associated $\beta$ galactosidase in $\mathrm{H}_{2} \mathrm{O}_{2}$-treated RCS cells. RCS cells were treated with $\mathrm{H}_{2} \mathrm{O}_{2}$ at indicated concentration for $2 \mathrm{~h}$ and after media change further incubated for $36 \mathrm{~h}$. bar: $200 \mu \mathrm{m}$.

CCN3 and p53 production in $\mathrm{H}_{2} \mathrm{O}_{2}$-treated RCS cells was also monitored by Western blot using an anti-CCN3 or anti-p53 antibody. CCN3 was accumulated in $\mathrm{H}_{2} \mathrm{O}_{2}$-treated RCS after 24 h incubation in a dose-dependent manner, but $48 \mathrm{~h}$ after the $\mathrm{H}_{2} \mathrm{O}_{2}$ treatment at the highest concentration, the amount of CCN3 as well as beta-actin decreased (Figure 2C). In contrast, p53 was accumulated in $\mathrm{H}_{2} \mathrm{O}_{2}$-treated RCS after $48 \mathrm{~h}$ incubation in a dose-dependent manner (Figure 2D), but not after $24 \mathrm{~h}$ incubation (data not shown), indicating p53 protein was accumulated after CCN3 protein was produced. Specificity of antisera against CCN3 was monitored by expressing green fluorescent protein (GFP)-fused CCN3 protein with or without Flag epitope using expression vector and those molecular weights were compared with Western blot signals obtained using anti GFP antibody (Figure 3A,B). 


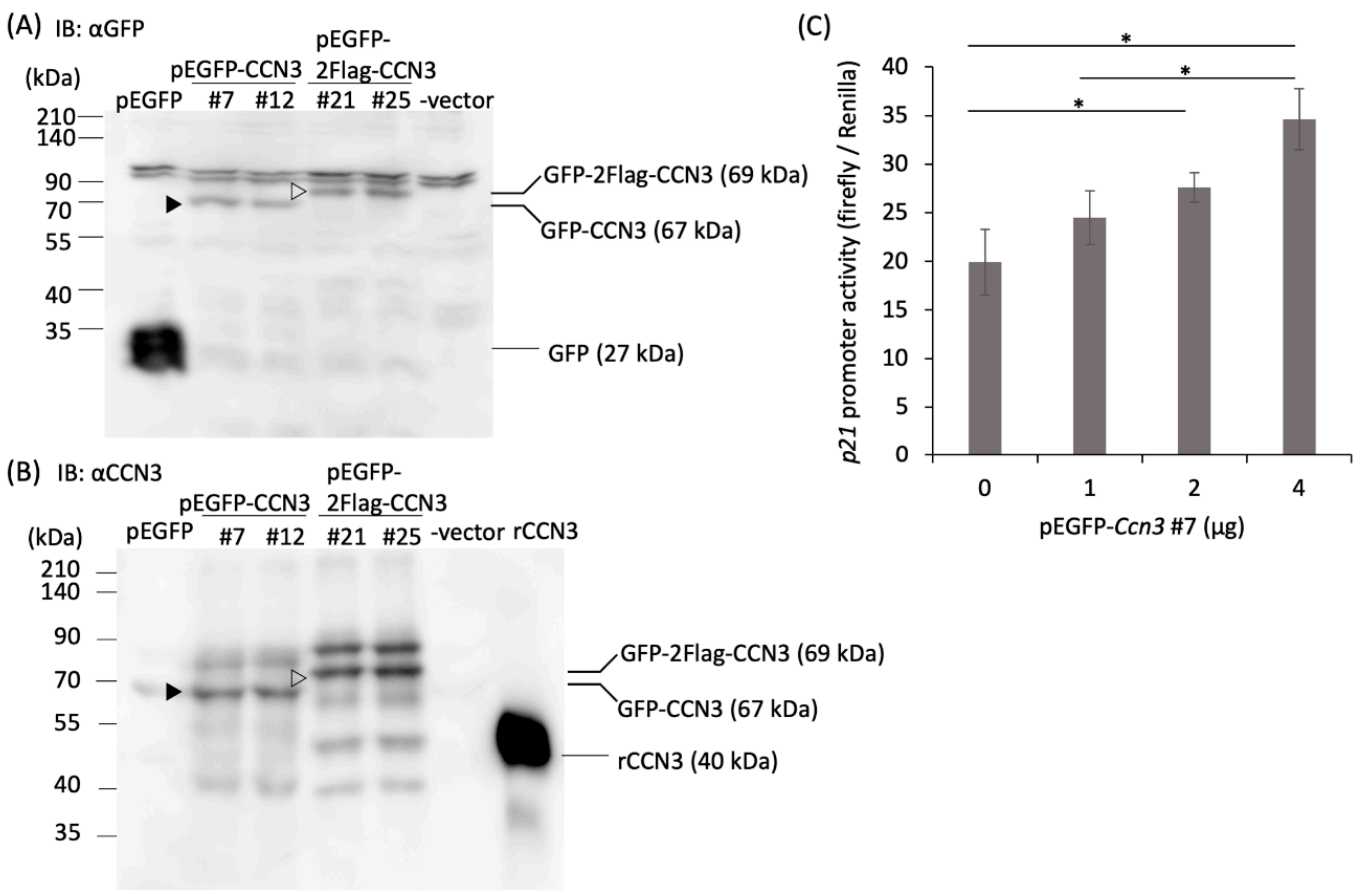

Figure 3. Induction of $p 21$ promoter activity by overexpression of CCN3 in RCS cells. Detection of GFP-CCN3 $(\triangleright)$ and GFP-2Flag-CCN3 $(\triangleright)$ overexpression with $(\mathbf{A})$ an anti-GFP antibody, and (B) anti-CCN3 antibody. Two days after transfection of pEGFP-CCN3 and pEGFP-2Flag-CCN3 vector ( 2 clones each) by electroporation, proteins were extracted from the cells and subjected to Western blot analysis. For the p21 promoter assay in (C), we used pEGFP-CCN3. (C) pEGFP-CCN3 vector, pGL3-PG12S containing $p 21$ promoter with $12 \times$ multiple p53-binding sites, and pGL3-Renilla vector were transfected by electroporation, and two days after transfection, firefly luciferase activity was monitored and standardized with Renilla luciferase activity (The data represent the mean $\pm \operatorname{SD}(n=3$ individual cultures); $\left.{ }^{*} p<0.05\right)$.

Cellular senescence induced by $\mathrm{H}_{2} \mathrm{O}_{2}$ treatment in RCS cells was also estimated by monitoring senescence associated (SA) $\beta$-gal activity. Thirty-six hours treatment with 100 and $200 \mu \mathrm{M} \mathrm{H}_{2} \mathrm{O}_{2}$ exhibited SA- $\beta$-gal positive senescent cells in RCS cells (Figure 2E).

\subsection{Overexpression of CCN3 Stimulates $p 21$ Promoter in RCS Cells}

To understand whether elevated CCN3 expression is a result of aging, or whether elevated CCN3 expression induces aging, we monitored the activity of a $p 21$ promoter with a plasmid construct harboring p53 binding sites after overexpression of CCN3 in RCS cells. CCN3 overexpression in RCS cells was confirmed by Western blot with both anti GFP antibody and CCN3 antibody (Figure 3A,B, $\bullet$ : GFP-CCN3 (67 kDa), $\triangleright$ : GFP-2xFlag-CCN3 $(69 \mathrm{kDa})$ ). Overexpression of GFP-tagged both CCN3 and Flag-CCN3 was also monitored with green fluorescent protein (data not shown). The $p 21$ promoter activity was monitored two days after transfection. Increased $p 21$ promoter activity was observed by cotransfection of the pEGFP-CCN3 vector in a dose-dependent manner (Figure $3 C^{*}{ }^{*}: p<0.05$ ). These results suggested that overexpression of CCN3 in RCS cells induces p21 expression through induction of p53.

\subsection{Treatment with CCN3 Stimulates p21, p53 mRNA Expression in Mouse Primary Chondrocytes and RCS Cells}

To see whether exogenously added CCN3 has ability to induce cell cycle arrest or not, recombinant (r) CCN3 was added to mouse primary articular chondrocytes from $2 \mathrm{~W}$ old knee joints and RCS cells. After $24 \mathrm{~h}$ incubation, total RNA was harvested and analyzed. 
As a result, p21 was used to standardize total amounts of cDNA; in some experiments, transmembrane protein 199 and p53 mRNA expression levels were significantly increased in both mouse primary chondrocytes (Figure 4A) and RCS cells (Figure 4B) by the addition of rCCN3 $\left({ }^{*} p<0.05\right.$, $* * p<0.01)$.
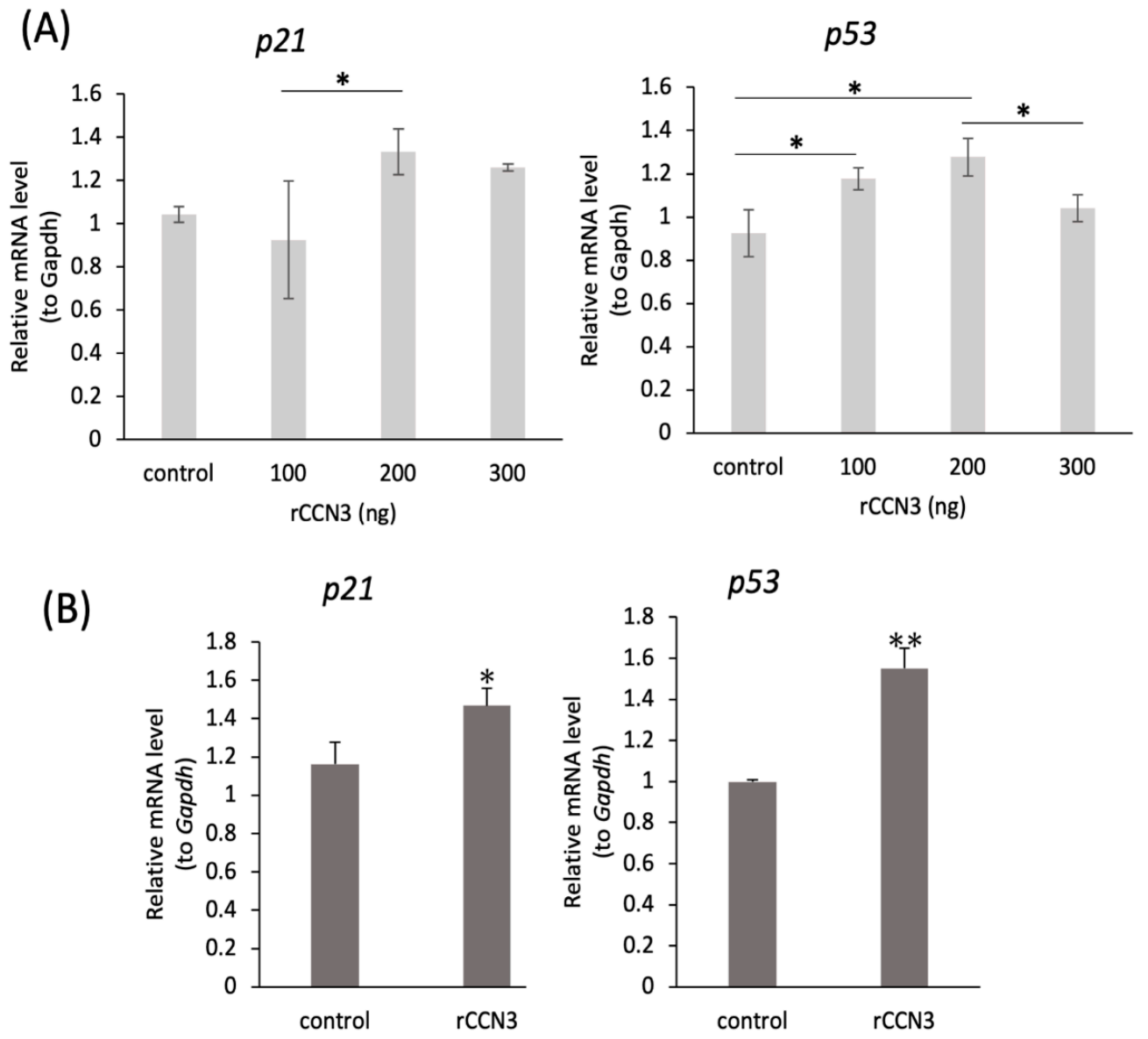

Figure 4. Stimulation of $p 21$ and $p 53$ mRNA expression by recombinant CCN3 treatment in (A) mouse primary articular chondrocytes from $2 \mathrm{w}$ knee joints and (B) RCS cells. Recombinant CCN3 was added to the media at indicated concentrations (A) and $100 \mu \mathrm{g} / \mathrm{mL}$ (B). Total RNA was harvested after $24 \mathrm{~h}$ incubation. The data represent the mean $\pm \operatorname{SD}\left(n=5\right.$ individual cultures). ${ }^{*} p<0.05,{ }^{* *} p<0.01$.

2.5. Cartilage-Specific CCN3 Overexpression Induced Degradative Changes in Articular Knee Joints and Rib Chondrocytes In Vitro

To further verify the function of CCN3 in vivo, we generated CCN3-overexpressing mice under the control of a $6 \mathrm{~kb}$-Col2a1 promoter that included a cartilage-specific enhancer in the first intron of the Col2a1 gene. The CCN3 gene was fused with the gene of green fluorescent protein (GFP), and IRES-LacZ was also built in to trace the transgene expression. The activity of beta-galactosidase in cartilage could be traced in up to 18-month-old knee joints (Figure 5A,B). Interestingly, Safranin-O staining of two-month-old knee joints showed degenerative changes, such as thinning of articular cartilage layers and surface roughening in transgenic mice (Figure 5C). Degenerative changes in articular cartilage were more severe in seven-month-old mice (Figure 5D). In addition, immunohistochemical staining for the aggrecan neoepitope in two-month-old knee joints showed positive staining in CCN3-overexpressing articular cartilage only, indicating that overexpressed CCN3 in cartilage induced degenerative changes in knee joints (Figure 5E). 
(A)

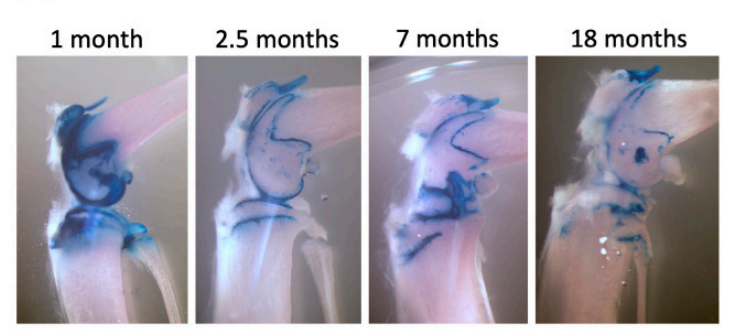

(B)

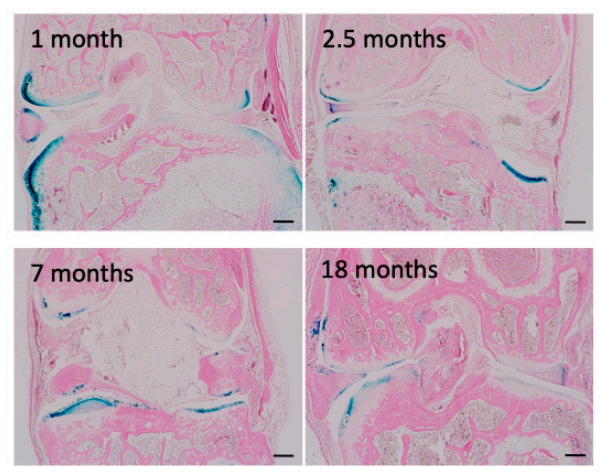

(D)

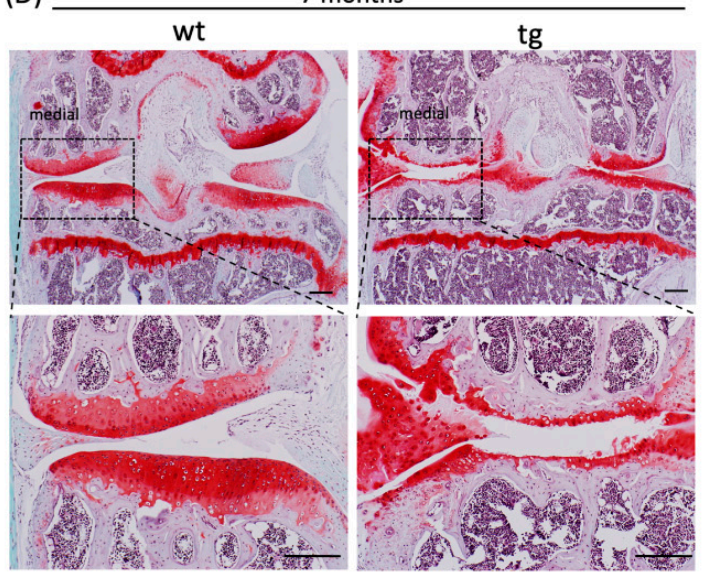

(C)

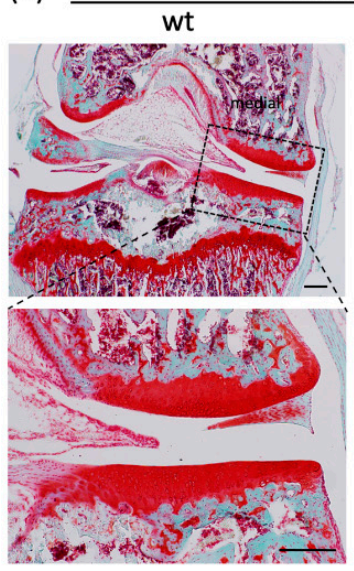

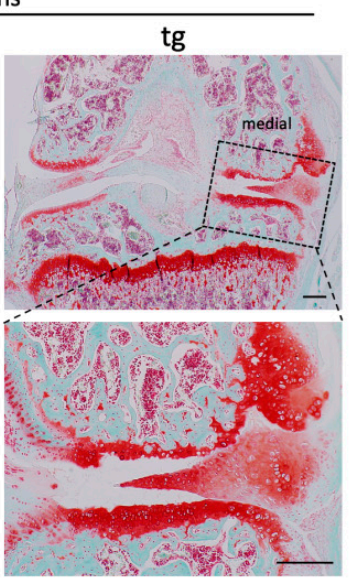

2 months

tg

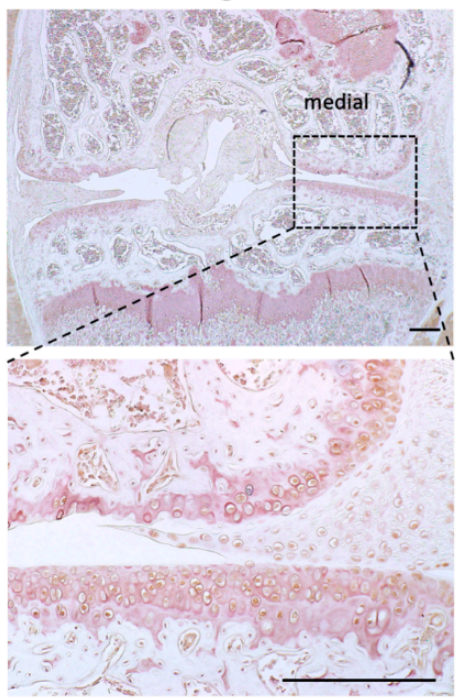

wt $-1^{\text {st }} A b$

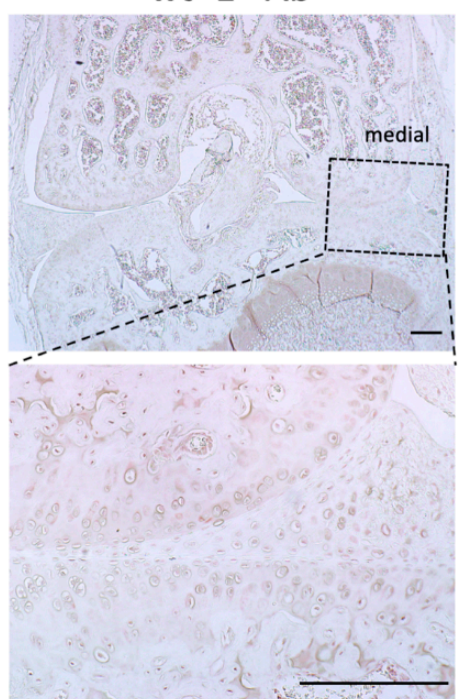

Figure 5. Cont. 
(F)
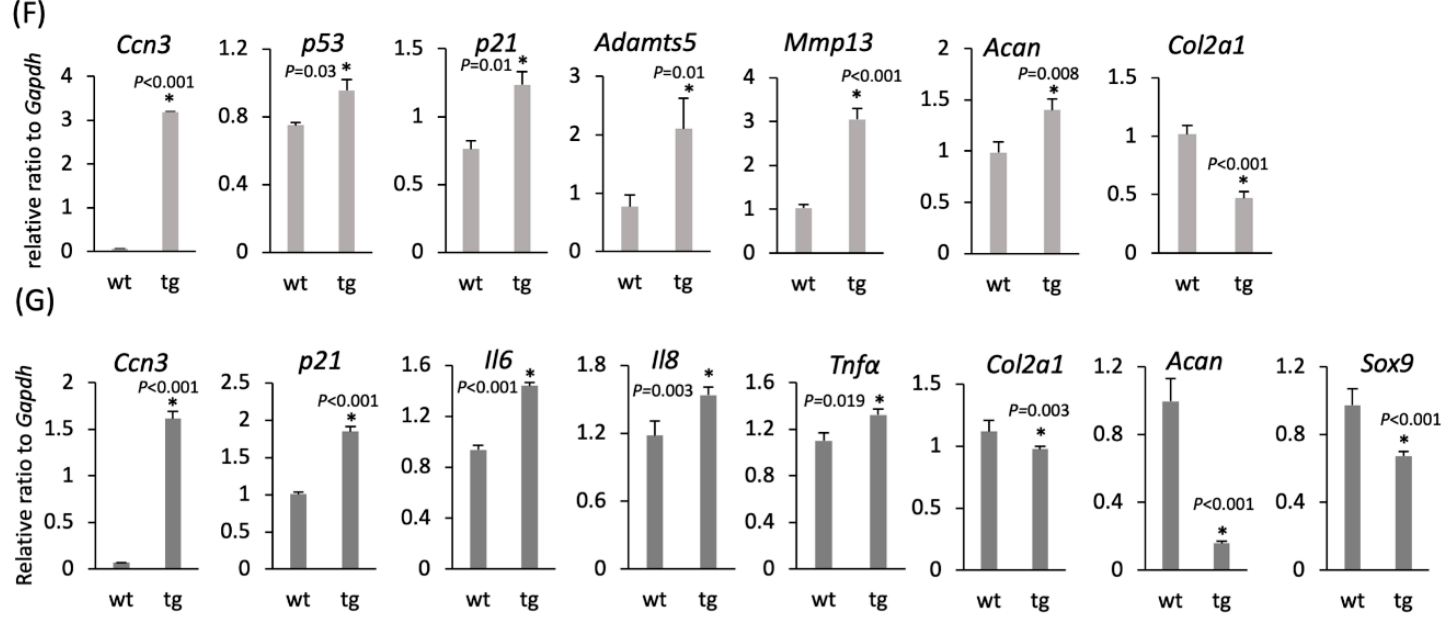

Figure 5. Degradative changes in knee joints and rib chondrocytes as a result of cartilage specific CCN3 overexpression in mice. (A) Whole mount LacZ staining of transgenic knee joints harboring a Col2a1 promoter-GFP-CCN3-LacZ construct (medial view). Beta-galactosidase activity was traceable up to 18 months after birth. (B) Histological analysis of (A) and counterstained with eosin. (C,D) Safranin-O staining of two-month-old (C) and seven-month-old (D) Ccn3 $3^{\text {tg }}$ mice. (E) Immunohistochemical staining of Aggrecan Neoepitope in two-month-old Ccn3 $3^{\text {tg }}$ mice knee articular cartilage. (wt -1st Ab) Negative control without 1st antibody of wt sections. (F,G) Analysis of gene expression of extracellular matrices and matrix metalloproteinases in chondrocyte RNA obtained from (F) rib cage chondrocytes of embryonic 18.5-day-old and (G) ribcages of three-month-old of tg mice. (F) Increased expression of p53, p21 and decreased expression Col2a1 mRNAs, were observed. (G) High expression levels of p21 and decreased expression levels of Col2a1, Acan, and Sox 9 were observed. Furthermore, the expression levels of inflammatory factors $I l 6, I l 8$, and Tnf $\alpha$ were increased. The $p 53$ expression did not show significant differences (data not shown). Scale bar: $200 \mu \mathrm{m}$.

Total RNA was obtained from the cultured primary chondrocytes of embryonic 18.5-day-old ribcages and those from the ribcage and articular cartilage of three-month-old transgenic mice. Even in 18.5-day-old Ccn3 transgenic rib chondrocytes, increased expression of $p 53, p 21$, Adamts5, and Mmp13 mRNA, and decreased expression of type II collagen was observed. The Acan expression level increased unexpectedly (Figure 5F, $p<0.01$ ). In three-month-old Ccn3 transgenic articular and ribcage cartilage, $p 21$, inflammatory factors of Il-6, Il-8, and Tnfo were induced; in contrast, Col2a1, Aggrecan, and Sox 9 mRNA were downregulated (Figure 5G, $p<0.01$ ). However, $p 53$ mRNA did not show a significant difference (data not shown).

\subsection{Elevation of $\mathrm{CCN} 3, p 53$, and $p 21$ mRNA Expression in Human Articular Cartilage with Age}

We also analyzed the expression level of CCN3 in human cartilage samples obtained after joint surgery. Cartilage samples were obtained from 14 patients aged 19 to 91 years who were relatively healthy in those years, without osteoarthritic degenerative changes. RT-qPCR analysis of primary cultured chondrocytes from articular cartilage showed a strong positive correlation between age and CCN3, $p 53$, and $p 21$ expression levels ( $r s: 0.8030808$ for CCN3/GAPDH, 0.7018706 for p53/GAPDH, 0.8294835 for $\mathrm{p} 21 / \mathrm{GAPDH}, p<0.01$, Figure $6 \mathrm{~A}$ ), which is similar to the results in mice (Figure 1 ). As note, similar to mouse chondrocytes, human articular chondrocytes also showed dramatically decreased GAPDH expression (see supplemental Figure S2). CCN3 mRNA level was also normalized with amount of RNA, and CCN3 mRNA still showed strong positive correlation between age (data not shown). Western blot analysis of cell lysates from 19- and 72-year-old primary articular chondrocytes showed CCN3 bands with different molecular weights (Figure 6B, see also Section 3). Immunohistochemical staining of $\mathrm{CCN} 3$ revealed strong positive staining in the superficial layer of femur articular cartilage in 74- and 81-year-old patients (Figure 6C). 
(A)
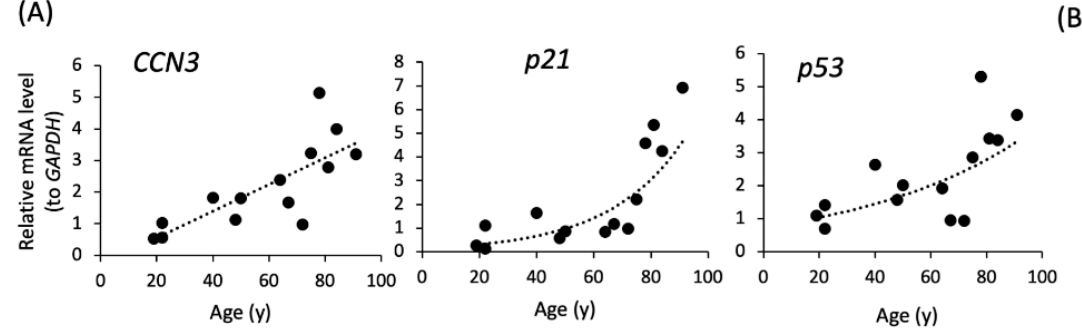

(B)

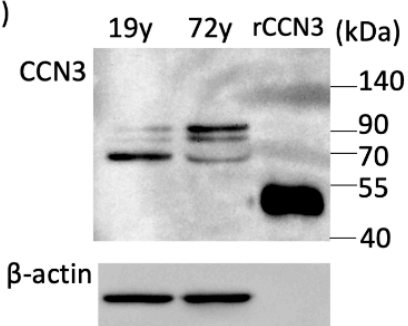

(C)

$6 y$

$48 y$

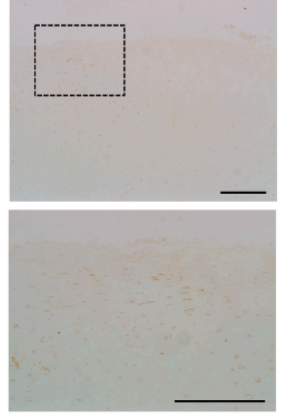

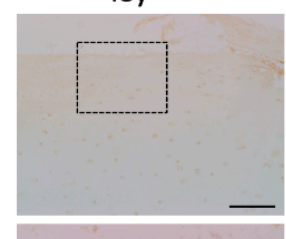

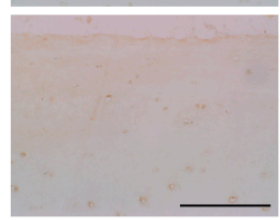

$74 y$

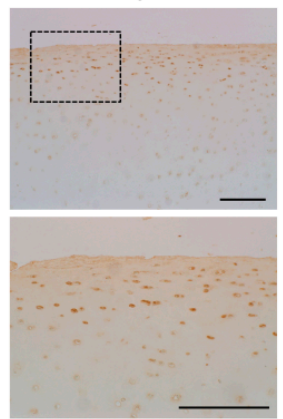

$81 y$

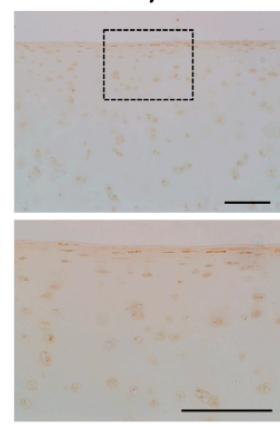

$74 y-1^{\text {st }} A b$

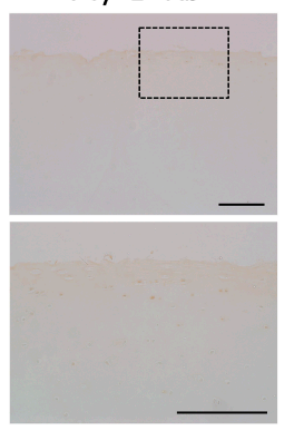

Figure 6. Elevated expression of Ccn3, p53, and p21 mRNA in aged human articular cartilage. (A) Comparison of mRNA expression levels of $C C N 3, p 53$, and $p 21$ in the primary culture of human articular chondrocytes at different ages. The expression level of Ccn3, p53, and $p 21 \mathrm{mRNA}$ was standardized to Gapdh. From one patient, articular cartilage was collected and digested, and cultured in multiple dishes. Total RNA was collected at least 3 dishes individually, and real time-PCR was performed in triplicates for each RNA sample; one 'dot' indicates average of gene expression level from one patient. (positive correlation, all $p<0.01$ ). (B) Western blot analysis of CCN3 protein in primary culture of the articular chondrocytes ( $8 \mu \mathrm{g}$ protein/lane) from different ages (y) as indicated. (C) Immunohistochemical staining of CCN3 in human articular cartilage (tibiae) of several ages. Top: lower magnification; bottom: higher magnification of the black square in the top. Scale bar: $200 \mu \mathrm{m}$.

\section{Discussion}

Osteoarthritic degenerative changes in articular cartilage are highly associated with chondrocyte senescence caused by aging. In this study, we explored the role of CCN3 in aging in articular cartilage. We observed significant induction of CCN3 in aging chondrocytes and in cells after oxidative stressinduced senescence. Mouse chondrocytes from older adults exhibited many changes in gene expression that are typical of senescent cells, such as induction of p21 and p53, mediators of cell cycle arrest, Il-6 and Il-8, as SASP factors, and reduction of the extracellular matrix gene, Acan. Our data support the hypothesis that the physiological stresses of aging induce the expression of cell cycle arrest genes, even in a hyporeplicative cell type such as chondrocytes.

A quantitative assessment of gene expression in aging cells is hampered by the observation that aging is associated with changes in gene expression levels that affect cellular functions, including cellular metabolism; therefore, housekeeping genes are also not always stably expressed [19]. Recently, transmembrane protein 199 (TMEM199) has been described as a new candidate reference gene to normalize the RT-qPCR data of senescent cells [20]. In our study, a significant increase in the expression of Ccn3 along with age was found by normalization, not only with Gapdh and RNA amount, but also with Tmem199. Increased expression of CCN3 with age was also observed in human articular cartilage. Changes in the expression of many marker genes in chondrocytes with age have been reported with or without cartilage degeneration [21,22]. The reported changes, however, have to be taken with care since many of the genes used as internal control show decreased expression along the age. For example, in this report, Col2a1 did not show expression changes with age when standardized to Gapdh. 
Sox9 mRNA expression showed positive correlation with age when standardized to Gapdh, in contrast, negative correlation was observed when normalized to total RNA.

Western blot analysis of human articular chondrocyte cell lysates showed CCN3 bands with different molecular weights between young and aged chondrocytes; CCN3 in aging chondrocytes showed a higher molecular weight, suggesting that CCN3 may undergo some modifications with age. Whether this modification changed the CCN3 activity or stability needs to be further elucidated.

Cellular senescence is a complex phenotype characterized by two parameters: durable cell cycle arrest induced by cellular stress; and the production of a set of pro-inflammatory molecules and matrix metalloproteinases known as the senescence-associated secretory phenotype (SASP) [23-25]. Artificially induced cellular senescence with oxidative stress by $\mathrm{H}_{2} \mathrm{O}_{2}$ in both human articular chondrocytes and RCS cells induced CCN3 mRNA in a dose dependent manner. Genes of cell cycle arrest, $p 21$ and $p 53$ mRNA were also induced in both cells dose dependently. Induction of CCN3 and p53 proteins by $\mathrm{H}_{2} \mathrm{O}_{2}$ was also examined in RCS cells. Activation of SA- $\beta$ gal was also detected in $\mathrm{H}_{2} \mathrm{O}_{2}$ treated RCS cells demonstrating $\mathrm{H}_{2} \mathrm{O}_{2}$ induced cellular senescence in cultured chondrocytes inducing CCN3 expression. Changing of mRNA expression of extracellular matrix was observed, but not in a dose-dependent manner. Expression of COL2A1 and Acan mRNA rather enhances in lower concentration of $\mathrm{H}_{2} \mathrm{O}_{2}$ in both primary chondrocytes and RCS cells, may indicating that mild damage of chondrocytes by oxidative stress rather induces synthesis of cartilaginous matrices observed in early stage of osteoarthritis [26]. Col10a1, Mmp13, and Adamts5 mRNA found in osteoarthritic cartilage $[27,28]$ were also strongly induced in $\mathrm{H}_{2} \mathrm{O}_{2}$ treated RCS cells, while a weaker response was seen in primary chondrocytes. This may be the reason that immortalized cell line could not survive when cell cycle was arrested, however, primary cultured cells go through maturation before death.

Not only elevated expression of CCN3 during aging and in induced senescent cells, but also overexpression of CCN3 or addition of recombinant CCN3 protein to cultured chondrocytes in vitro was found to induce cell cycle arrest by upregulating $p 53$ and $p 21$.

Furthermore, CCN3 overexpression in articular cartilage in vivo not only affected cell cycle regulation but also induced characteristic features of senescence. In this report, severe degenerative changes were observed in CCN3-overexpressing articular cartilage. For the gene expression analysis, we isolated primary chondrocytes from rib cages of embryonic 18.5 days, and rib cage cartilage of 3 month old transgenic and wild type mice of the same littermates. Even in 3 month rib cage cartilage, CCN3 induced Il-6, Il-8, and Tnfo which are considered as general SASP factors and also osteoarthritic proinflammatory degenerative markers in articular cartilage. In addition, decreased expression of Col2a1 and Acan mRNA was observed, which is consistent with a previous result [18]. However, Mmp13 and Adamts5 mRNA were not upregulated in three-month old rib chondrocytes in contrast to articular cartilage. p53 mRNA was not also elevated in three-month old rib RNA sample, this may be due to the stably translated p53 protein level or p21 protein level. In E18.5-Ccn3 transgenic chondrocytes, elevated expression of $p 53, p 21$, Adamts5, and Mmp13 mRNA was observed, but SASP factors such as $\mathrm{Il}-6, \mathrm{Il}-8$, and $\mathrm{Tnf} \alpha$ were not induced (data not shown), indicating that the induction of those factors only occurs after birth.

A physiological interaction between $\mathrm{CCN} 3$ and $\mathrm{p} 53$ has not been reported so far. It is possible that p53 regulates $\mathrm{C} c n 3$ transcription or that $\mathrm{CCN} 3$ protein may upregulate another transcription factor(s) which is induced along aging to upregulate $\mathrm{p} 53$. It is also possible that CCN3 protein may itself form complexes that regulate cell cycle. Further studies will be necessary to clarify this problem.

Two different lines of CCN3-deficient mice have been reported: CCN3-deficient mice in which exons 1 and 2 and part of exon 3 are replaced by the neomycin cassette showed enhanced neointimal hyperplasia in response to injury. This is caused by repressing the inhibitory effects of $\mathrm{CCN} 3$ on vascular smooth muscle cell proliferation, which is mediated by induction of p21 and p15 [29]. This report is in line with our observation that CCN3 induced p21 and p53 expression in chondrocytes. In our data, there was an increase in the expression level of p21 but not of p53 in three-month-old CCN3-overexpressing cartilage. However, our finding that both treatment with recombinant CCN3 
and CCN3 overexpression significantly increased the p53 expression indicates that p53 regulation by $\mathrm{CCN} 3$ also occurs in chondrocytes. The other CCN3-deficient mice caused by deletion of exon 3 showed skeletal abnormalities in some joints and heart defects [30]; 12-month-old male knee joints showed some degenerative changes, but female joints did not [31]. Since these CCN3-deficient mice were able to express the first 1 and 2 domains coded by exon 1 and 2, the phenotypes of these mice must be interpreted with care. Whether those mice show prolonged life or anti-aging phenotype, or not, needs to be analyzed.

Although the precise molecular mechanism of regulation of the cell cycle by CCN3 is still unclear, there are several reports that $\mathrm{CCN} 3$ regulates $\mathrm{NOTCH} 1$ signaling [32]. The detailed signaling mechanism of cell cycle control by CCN3 in adult articular cartilage should be investigated in future studies.

The accumulation of senescent cells with aging contributes to age-related tissue dysfunction [33]. However, cellular senescence has also been considered as a protective system against tumorigenesis. CCN3 has antiproliferative activities in several tumor cell lines [34-36]. In addition, CCN3 was previously shown to be induced by glucose starvation [37]. Another report suggests that recombinant CCN3 ameliorates $1 \mathrm{~L}-1 \beta$ induced metalloproteinases in cultured chondrocytes by the activation of PI3K/AKT/mTOR pathway [38,39]. Taking these facts into consideration, it is assumed that the observed CCN3 induction may be a protective response against multiple stimuli such as age-related oxidative stress and nutrition shortages.

\section{Conclusions}

$\mathrm{CCN} 3$ can be a new marker of chondrocyte senescence, and CCN3 accelerates cellular senescence via induction of $p 53$ and $p 21$.

\section{Materials and Methods}

\subsection{Cell Cultures}

Mouse primary articular chondrocytes were isolated from neonatal day 2 to 37 -week-old articular cartilage; primary ribcage chondrocytes were isolated from embryonic 18.5-day- and three-month-old C57BL/6J mice, as previously described [40,41].

Human articular chondrocytes were obtained from patients with informed consent upon orthopedic surgery in a traumatic clinical case approved by the Ethics Committee of Okayama University Graduate School of Medicine, Dentistry, and Pharmaceutical Sciences (\#K1506-018). Pieces of knee articular cartilage were treated similarly to mouse articular cartilage, except for overnight digestion with $2 \%$ collagenase. Rat chondrosarcoma-derived cells (RCS) were provided by Dr. Benoit de Crombrugghe (The University of Texas MD Anderson Cancer Center, Houston, TX, USA) [42]. Cells were cultured in Dulbecco's modified Eagle's medium (DMEM) containing 10\% fetal bovine serum (FBS) at $37^{\circ} \mathrm{C}$ with $5 \% \mathrm{CO}_{2}$. Before the addition of recombinant mouse CCN3 (see Section 2.6), RCS cells were cultured with DMEM containing $0.5 \%$ FBS for $24 \mathrm{~h}$. All animal experiments were conducted in accordance with the institutional rules under the approval from the Animal Care and Use Committee of Okayama University, Okayama, Japan (OKU-2018903, OKU-2018023, OKU-2020328).

\subsection{Isolation of Total RNA}

Total RNA from cultured cells was extracted and purified using a RNeasy Mini Kit (Qiagen, Hilden, Germany). For cartilage, tissues were homogenized with ISOGEN (Nippon Gene, Toyama, Japan), and total RNA was further purified by a RNeasy Mini Kit, according to the manufacturer's instructions.

\subsection{Real-Time Polymerase Chain Reaction}

Total RNAs were reverse-transcribed by a PrimeScript RT-reagent Kit (Takara Bio, Shiga, Japan). Subsequent quantitative real-time PCR was performed using SYBR ${ }^{\circledR}$ Green Realtime PCR Master Mix 
(Toyobo Osaka, Japan) with a StepOnePlus ${ }^{\mathrm{TM}}$ (Applied Biosystems, Basel, Switzerland) Real-Time PCR System. The primers used are listed in Tables 1-3. Expression of Gapdh was used to standardize total amounts of cDNA; in some experiments, transmembrane protein 199 (Tmem199) or the amount of total RNA was used for standardization.

Table 1. Primer sequences for mouse tissues.

\begin{tabular}{ccc}
\hline Gene & Forward & Reverse \\
\hline Ccn3 & cagacccaacaaccagact & acttctctcottgcggtaa \\
$p 16$ & gaactcttcggtcgtaccc & agttcgaatctgcaccgtagt \\
$p 21$ & gaacatctcagggccgaaaa & tgcgcttggagtgatagaaatc \\
p53 & tcttatccgggtggaaggaaa & ggcgaaaagtctgcctgtctt \\
Aggrecan & gaggagagaactggagaag & ggcgatagtggaatacaa \\
Col2a1 & tggtggagcagcaagagcaa & cagtggacagtagacggaggaaa \\
Col10a1 & tgctgcctcaaatacctttct & tggcgtatgggatgaagtattg \\
Sox9 & atctgaagaaggagagcgag & tcagaagtctccagagcttg \\
Il-6 & ggagcccaccaagaacgata & tcccaagaaggcaactggat \\
Il-8 & aatttccaccggcaatgaag & cccgaattggaaagggaaat \\
Mmp13 & tcctcggagactggtaatgg & tgatgaaacctggacaagca \\
Adamts-5 & ggcatcattcatgtgacac & gcatcgtaggtctgtcctg \\
Tnf $\alpha$ & aggggattatggctcagggt & tgagtccttgatggtggtgc \\
Tmem199 & aaatggcgtcttcttgcttgc & atcactgcccgcgtgtttctt \\
Gapdh $*$ & caatgacccttcattgacc & gacaagcttccottctcag \\
\hline
\end{tabular}

* Common to mice, RCS, and humans.

Table 2. Primer sequences for RCS.

\begin{tabular}{ccc}
\hline Gene & Forward & Reverse \\
\hline Cn3 & tgaagtctctgactccagcatt & tggctttcagggatttcttg \\
$p 21$ & caaagtatgccgtcgtctgttc & gaagtcaaagttccaccgttctc \\
$p 53$ & tccgactataccactatccactaca & ggcacaaacacgaacctcaaa \\
Aggrecan & agaatcaagtggagccgtgtt & ggggatggctggatagttgg \\
Col2a1 & ctcacgccttccattgttg & gttgtttggggttgagggttt \\
Col10a1 & acctcccacccattcca & acccactattgctgctcactc \\
Mmp13 & tgcggttcacttgaggaca & tcttcttctatgaggcgggga \\
Adamts-5 & tagaccctacagcaactccgt & cctccacacactccacactt \\
\hline
\end{tabular}

Table 3. Primer sequences for humans.

\begin{tabular}{ccc}
\hline Gene & Forward & Reverse \\
\hline$C C N 3$ & ggagcgcgctataaaactt & tccctctcgcttttaccaa \\
$p 21$ & tggggctgggagtagttgt & gctggaaggtgtttggggt \\
$p 53$ & ggtcggtgggttggtagtt & gtgtgggatggggtgagattt \\
\hline
\end{tabular}

\subsection{Histology}

Knee joints were fixed with $10 \%$ formaldehyde/PBS, demineralized with 0.5 M EDTA, dehydrated, and embedded in paraffin. After the tissues were embedded in paraffin, serial frontal sections of $5 \mu \mathrm{m}$ thickness were cut through the knee joints.

\subsection{Immunohistochemistry}

Immunohistochemistry was done as reported previously [40,41]. Sections of knee joints were treated with bovine testicular hyaluronidase $(10 \mathrm{mg} / \mathrm{mL})$ for $30 \mathrm{~min}$ at room temperature for epitope retrieval, followed by $10 \% \mathrm{H}_{2} \mathrm{O}_{2}$ in methanol for $10 \mathrm{~min}$ to inactivate endogenous peroxidase, and then were immunostained with anti-CCN3 (provided by Dr. Takako Sasaki), or anti-aggrecan neo-epitope (Novus Biologicals, Littleton, CO, USA) antibody. The signal was enhanced with Envision+ Dual 
Link System Peroxidase (Dako, Glostrup, Denmark) and developed with DAB (2 mg/mL). In some experiments, the sections were counter-stained with methyl green.

\subsection{Recombinant Mouse CCN3 and CCN3 Antibody}

Protein coding region of mouse Ccn3 cDNA (NM_010930.5) including signal peptide was cloned into the pCEP vector. The expression construct was transfected into 293 EBNA cells and serum-free conditioned media were collected. The conditioned media were loaded onto DEAE cellulose (DE52) equilibrated with $0.05 \mathrm{M}$ Tris-HCl, $\mathrm{pH} 8.6$ and eluted with a linear $0-0.5 \mathrm{M} \mathrm{NaCl}$ gradient in DEAE buffer. Fractions containing $\mathrm{CCN} 3$ protein were concentrated by ammonium sulfate, and further purified on Superose $12 \mathrm{HR} 15 / 60$ column eqilibrated with $0.2 \mathrm{M}$ ammonium acetate. The CCN3 protein was dialyzed against PBS before addition to the cells.

CCN3 antiserum was obtained by immunizing rabbits with mrCCN3. For Western blot, 1:500 dilution, and for immunohistochemistry, 1:50 dilution were used. Specificity of antiserum was monitored by comparison of the staining signal between $\mathrm{CCN} 3 \mathrm{tg}$ and wild type cartilage (supplemental Figure S3).

\subsection{Treatment with $\mathrm{H}_{2} \mathrm{O}_{2}$}

After RCS cells reached confluence, the cells were exposed to 100-400 $\mu \mathrm{M} \mathrm{H}_{2} \mathrm{O}_{2}$ for $2 \mathrm{~h}$. The cells were washed with DMEM and replenished with a fresh medium containing $10 \%$ FBS. Total RNAs were collected after $24 \mathrm{~h}$ incubation, and cell lysates were collected after 24 and $48 \mathrm{~h}$ incubation.

\subsection{Western Blots}

Cultured cells were washed with PBS and harvested with $10 \mathrm{mM}$ Tris- $\mathrm{HCl}$ (pH 8.0) in $150 \mathrm{mM}$ $\mathrm{NaCl}, 1 \%$ Triton X-100, and $0.1 \mathrm{mM}$ phenylmethylsulphonyl fluoride. After the removal of precipitates, $5 \mu \mathrm{g}$ of total protein were subjected to Western blot analysis. Primary antibodies against CCN3 (provided by Dr. Takako Sasaki, Oita University) and $\beta$-actin (Sigma, St Louis, MO, USA) were used.

\subsection{Plasmids}

For overexpression of CCN3 in RCS cells, mouse Ccn3 cDNA was ligated into a pEGFP-N1 vector (Clontech). For $p 21$ reporter gene assay, a firefly luciferase reporter vector, pGL3-PG12S (kindly provided by Dr. Inoue, Wakayama Medical University) containing $12 \times$ multiple p53-binding sites upstream of the $S V 40$ promoter, and the pGL3-Renilla vector, harboring renilla luciferase, were used.

\subsection{0. p21 Promoter Reporter Gene Assay}

RCS cells were seeded in 12-well plates at a density of $8.0 \times 10^{4}$ cells/well and incubated for $24 \mathrm{~h}$. The medium was changed, and pGL3-PG12S, pGL3-Renilla, and various amounts of pEGFP-CCN3 were cotransfected into the RCS cells with PEI-MAX (kindly provided by Dr. Takarada, Okayama University) according to the manufacturer's instructions. Twenty-four hours after DNA transfection, luciferase activities were measured using a Dual-Glo Luciferase Assay System (Promega). The transfection efficiency was normalized to Renilla luciferase activity expressed from pGL3-Renilla. Mean values were calculated from the results of three independent experiments.

\subsection{Generation of Transgenic Mice}

Ccn3 transgenic $\left(\mathrm{C} c n 3^{\mathrm{Tg}}\right)$ mice were generated and maintained in the C57BL/6J background, in which murine Ccn3 fused with green fluorescent protein (GFP, Invitrogen, Carlsbad, CA, USA) and IRES (internal ribosome entry site)-LacZ was driven under the control of the 6-kb Col2a1 promoter-enhancer. The sequences of PCR primers used for genotyping were $5^{\prime}$-GCATCGAGCTG GGTAATAAGCGTTGGCAAT- ${ }^{\prime}$ and 5'-GACACCAGACCAACTGGTAATGGTAGCGAC-3' ${ }^{\prime}$, which detects a fragment of $L a c Z$. 
The knee joints and rib cartilage of sacrificed mice were isolated for RT-qPCR and histology. All mice were housed in filter-top cages with paper-chip bedding under standard pathogen-free conditions. The mice were fed a standard diet with tap water provided ad libitum.

\subsection{X-Gal Staining}

To trace transgene expression in articular cartilage, beta-galactosidase activity was monitored from 1-, 2.5-, 7-, and 18-month-old transgenic knee joints using X-gal (5-bromo-4-chloro-3-indolyl-Dgalactopyranoside, Roche, Basel, Switzerland) as a substrate, as described before [41]. For staining of knee joints, skin and muscle were removed before fixation. X-gal-stained knee joints were postfixed overnight in $4 \%$ formaldehyde, dehydrated, and embedded in paraffin. Seven-micrometer-thick sections were prepared by standard methods and counterstained with eosin.

For monitoring SA- $\beta$ gal activity, the cells were fixed with $4 \%$ formaldehyde, and after washing with PBS, the cells were stained with citric acid/sodium phosphate buffer $(\mathrm{pH}$ 6.4) containing $5 \mathrm{mM}$

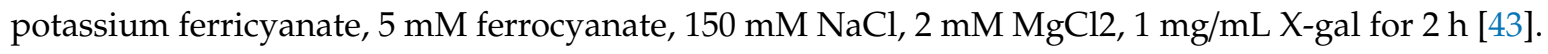

\subsection{Safranin-O Staining}

Safranin-O-fast green staining were used to analyze proteoglycan in articular cartilage.

\subsection{Statistic Analysis}

Data are presented as means \pm standard deviation. The Spearman correlation coefficient was used to explore possible associations between variables. Tukey's multiple comparison tests was used to determine the overall differences between groups. Unpaired Student's $t$-tests were used for comparisons between the control and subjects to determine significant differences. All calculations were performed using statistical web software (http://www.gen-info.osaka-u.ac.jp/testdocs/tomocom/, Osaka University, Japan). Values of $p<0.05$ were considered statistically significant.

Supplementary Materials: The following are available online at http://www.mdpi.com/1422-0067/21/20/7556/s1.

Author Contributions: Conceptualization, M.K. and T.H.; methodology, M.K., K.K., S.K. (Sei Kondo), S.F., Y.M., A.O., M.O., T.F., E.N., and T.S.; validation, S.K. (Satoshi Kubota) and T.H.; formal analysis, T.H.; investigation, M.K., K.K., and T.H.; data curation, T.H.; writing-original draft preparation, M.K. and T.H.; writing-review and editing, T.H.; supervision, S.M., S.K. (Satoshi Kubota), and T.H.; project administration, T.H.; funding acquisition, M.K., M.T., and T.H. All authors have read and agreed to the published version of the manuscript.

Funding: This work was supported by JSPS KAKENHI Grant Numbers 16K11476 and 25462888 to T.H.,19K22716 to S.K. (Satoshi Kubota), and 20K18601 to M.K., as well as funding from the Foundation for Growth Science to T.H., a Ryobi Teien Foundation award to T.H., and a SHISEIKAI Scholarship Fund for basic medical science researchers (Keiko Watanabe Award) to T.H.

Acknowledgments: The authors thank Tetsuya Hara, Takashi Nishida, Takeshi Takarada, Daisuke Yamada, and Mika Ikegame for useful suggestions, and Mayumi Ohta for secretarial assistance.

Conflicts of Interest: The authors declare no conflict of interest.

\section{References}

1. Hermann, W.; Lambova, S.; Ladner, U.M. Current Treatment Options for Osteoarthritis. Curr. Rheumatol. Rev. 2018, 14, 108-116. [CrossRef] [PubMed]

2. Ashford, S.; Williard, J. Osteoarthritis: A review. Nurse Pract. 2014, 39, 1-8. [CrossRef] [PubMed]

3. Hou, A.; Chen, P.; Tang, H.; Meng, H.; Cheng, X.; Wang, Y.; Zhang, Y.; Peng, J. Cellular senescence in osteoarthritis and anti-aging strategies. Mech. Ageing Dev. 2018, 175, 83-87. [CrossRef] [PubMed]

4. Livshits, G.; Zhai, G.; Hart, D.J.; Kato, B.S.; Wang, H.; Williams, F.M.; Spector, T.D. Interleukin-6 is a significant predictor of radiographic knee osteoarthritis: The Chingford study. Arthritis Rheum. 2009, 60, 2037-2045. [CrossRef] 
5. Philipot, D.; Guérit, D.; Platano, D.; Chuchana, P.; Olivotto, E.; Espinoza, F.; Dorandeu, A.; Pers, Y.M.; Piette, J.; Borzì, R.M.; et al. p16INK4a and its regulator miR-24 link senescence and chondrocyte terminal differentiation-associated matrix remodeling in osteoarthritis. Arthritis Res. Ther. 2014, 16, R58. [CrossRef]

6. Ashraf, S.; Cha, B.-H.; Kim, J.-S.; Ahn, J.; Han, I.; Park, H.; Lee, S.-H. Regulation of senescence associated signaling mechanisms in chondrocytes for cartilage tissue regeneration. Osteoarthr. Cartil. 2016, 24, 196-205. [CrossRef]

7. Tsuchida, A.I.; Beekhuizen, M.; Hart, M.C.; Radstake, T.R.; Dhert, W.J.A.; Saris, D.B.F.; Van Osch, G.J.V.M.; Creemers, L. Cytokine profiles in the joint depend on pathology, but are different between synovial fluid, cartilage tissue and cultured chondrocytes. Arthritis Res. 2014, 16, 441. [CrossRef]

8. Hui, W.; Young, D.A.; Rowan, A.D.; Xu, X.; Cawston, T.E.; Proctor, C.J. Oxidative changes and signalling pathways are pivotal in initiating age-related changes in articular cartilage. Ann. Rheum. Dis. 2015, 75, 449-458. [CrossRef]

9. Wang, Y.; Zhao, X.; Lotz, M.; Terkeltaub, R.; Liu-Bryan, R. Mitochondrial Biogenesis Is Impaired in Osteoarthritis Chondrocytes but Reversible via Peroxisome Proliferator-Activated Receptor $\gamma$ Coactivator $1 \propto$. Arthritis Rheumatol. 2015, 67, 2141-2153. [CrossRef]

10. Blanco, F.J.; Rego, I.; Ruiz-Romero, C.; Blanco, F.J.; Rego-Perez, I. The role of mitochondria in osteoarthritis. Nat. Rev. Rheumatol. 2011, 7, 161-169. [CrossRef]

11. Ulgherait, M.; Rana, A.; Rera, M.; Graniel, J.; Walker, D.W. AMPK Modulates Tissue and Organismal Aging in a Non-Cell-Autonomous Manner. Cell Rep. 2014, 8, 1767-1780. [CrossRef] [PubMed]

12. Caramés, B.; Olmer, M.; Kiosses, W.B.; Lotz, M.K. The relationship of autophagy defects to cartilage damage during joint aging in a mouse model. Arthritis Rheumatol. 2015, 67, 1568-1576. [CrossRef] [PubMed]

13. Caramés, B.; Taniguchi, N.; Otsuki, S.; Blanco, F.J.; Lotz, M.K. Autophagy is a protective mechanism in normal cartilage, and its aging-related loss is linked with cell death and osteoarthritis. Arthritis Rheum. 2010, 62, 791-801. [CrossRef] [PubMed]

14. Verzijl, N.; DeGroot, J.; Ben Zaken, C.; Braun-Benjamin, O.; Maroudas, A.; Bank, R.A.; Mizrahi, J.; Schalkwijk, C.G.; Thorpe, S.R.; Baynes, J.W.; et al. Crosslinking by advanced glycation end products increases the stiffness of the collagen network in human articular cartilage: A possible mechanism through which age is a risk factor for osteoarthritis. Arthritis Rheum. 2002, 46, 114-123. [CrossRef]

15. Holbourn, K.P.; Acharya, K.R.; Perbal, B. The CCN family of proteins: Structure-function relationships. Trends Biochem. Sci. 2008, 33, 461-473. [CrossRef] [PubMed]

16. Takigawa, M.; Takigawa, M. The CCN Proteins: An Overview. Adv. Struct. Saf. Stud. 2016, 1489, 1-8. [CrossRef]

17. Leask, A.; Abraham, D.J. All in the CCN family: Essential matricellular signaling modulators emerge from the bunker. J. Cell Sci. 2006, 119, 4803-4810. [CrossRef] [PubMed]

18. Kawaki, H.; Kubota, S.; Suzuki, A.; Lazar, N.; Yamada, T.; Matsumura, T.; Ohgawara, T.; Maeda, T.; Perbal, B.; Lyons, K.M.; et al. Cooperative Regulation of Chondrocyte Differentiation by CCN2 and CCN3 Shown by a Comprehensive Analysis of the CCN Family Proteins in Cartilaget. J. Bone Miner. Res. 2008, 23, 1751-1764. [CrossRef]

19. Eisenberg, E.; Levanon, E.Y. Human housekeeping genes, revisited. Trends Genet. 2013, $29,569-574$. [CrossRef]

20. Hernandez-Segura, A.; Rubingh, R.; DeMaria, M. Identification of stable senescence-associated reference genes. Aging Cell 2019, 18, e12911. [CrossRef]

21. Chambers, M.G.; Kuffner, T.; Cowan, S.K.; Cheah, K.S.E.; Mason, R.M. Expression of collagen and aggrecan genes in normal and osteoarthritic murine knee joints. Osteoarthr. Cartil. 2002, 10, 51-61. [CrossRef] [PubMed]

22. Loeser, R.F.; Olex, A.L.; McNulty, M.A.; Carlson, C.S.; Callahan, M.F.; Ferguson, C.M.; Chou, J.; Leng, X.; Fetrow, J.S. Microarray analysis reveals age-related differences in gene expression during the development of osteoarthritis in mice. Arthritis Rheum. 2012, 3, 705-717. [CrossRef] [PubMed]

23. Childs, B.G.; Durik, M.; Baker, D.J.; Van Deursen, J.M. Cellular senescence in aging and age-related disease: From mechanisms to therapy. Nat. Med. 2015, 21, 1424-1435. [CrossRef] [PubMed]

24. Coppé, J.-P.; Desprez, P.-Y.; Krtolica, A.; Campisi, J. The Senescence-Associated Secretory Phenotype: The Dark Side of Tumor Suppression. Annu. Rev. Pathol. Mech. Dis. 2010, 5, 99-118. [CrossRef] 
25. Muñoz-Espín, D.; Serrano, M. Cellular senescence: From physiology to pathology. Nat. Rev. Mol. Cell Biol. 2014, 15, 482-496. [CrossRef]

26. Aigner, T.; Dudhia, J. Phenotypic modulation of chondrocytes as a potential therapeutic target in osteoarthritis: A hypothesis. Ann. Rheum. Dis. 1997, 56, 287-291. [CrossRef]

27. Troeberg, L.; Nagase, H. Proteases involved in cartilage matrix degradation in osteoarthritis. Biochim. Biophys. Acta. 2012, 1824, 133-145. [CrossRef]

28. Kamekura, S.; Hoshi, K.; Shimoaka, T.; Chung, U.; Chikuda, H.; Yamada, T.; Uchida, M.; Ogata, N.; Seichi, A.; Nakamura, K.; et al. Osteoarthritis development in novel experimental mouse models induced by knee joint instability. Osteoarthritis Cartilage 2005, 13, 632-641. [CrossRef]

29. Shimoyama, T.; Hiraoka, S.; Takemoto, M.; Koshizaka, M.; Tokuyama, H.; Tokuyama, T.; Watanabe, A.; Fujimoto, M.; Kawamura, H.; Sato, S.; et al. CCN3 Inhibits Neointimal Hyperplasia Through Modulation of Smooth Muscle Cell Growth and Migration. Arter. Thromb. Vasc. Biol. 2010, 30, 675-682. [CrossRef]

30. Heath, E.; Tahri, D.; Andermarcher, E.; Schofield, P.N.; Fleming, S.; Boulter, C.A. Abnormal skeletal and cardiac development, cardiomyopathy, muscle atrophy and cataracts in mice with a targeted disruption of the Nov (Ccn3) gene. BMC Dev. Biol. 2008, 8, 18. [CrossRef]

31. Roddy, K.; Boulter, C. Targeted mutation of NOV/CCN3 in mice disrupts joint homeostasis and causes osteoarthritis-like disease. Osteoarthr. Cartil. 2015, 23, 607-615. [CrossRef] [PubMed]

32. Suresh, S.; McCallum, L.; Crawford, L.J.; Lu, W.H.; Sharpe, D.J.; Irvine, A.E. The matricellular protein CCN3 regulates NOTCH1 signalling in chronic myeloid leukaemia. J. Pathol. 2013, 231, 378-387. [CrossRef] [PubMed]

33. He, S.; Sharpless, N.E. Senescence in Health and Disease. Cell 2017, 169, 1000-1011. [CrossRef] [PubMed]

34. Joliot, V.; Martinerie, C.; Dambrine, G.; Plassiart, G.; Brisac, M.; Crochet, J.; Perbal, B. Proviral rearrangements and overexpression of a new cellular gene (nov) in myeloblastosis-associated virus type 1-induced nephroblastomas. Mol. Cell. Biol. 1992, 12, 10-21. [CrossRef] [PubMed]

35. Chevalier, G.; Yeger, H.; Martinerie, C.; Laurent, M.; Alami, J.; Schofield, P.N.; Perbal, B. novH: Differential expression in developing kidney and Wilm's tumors. Am. J. Pathol. 1998, 152, 1563-1575.

36. Yu, C.; Le, A.-T.; Yeger, H.; Perbal, B.; Alman, B.A. NOV (CCN3) regulation in the growth plate and CCN family member expression in cartilage neoplasia. J. Pathol. 2003, 201, 609-615. [CrossRef]

37. Akashi, S.; Nishida, T.; El-Seoudi, A.; Takigawa, M.; Iida, S.; Kubota, S. Metabolic regulation of the CCN family genes by glycolysis in chondrocytes. J. Cell Commun. Signal. 2017, 12, 245-252. [CrossRef]

38. Huang, X.; Ni, B.; Mao, Z.; Xi, Y.; Chu, X.; Zhang, R.; Ma, X.; You, H. NOV/CCN3 induces cartilage protection by inhibiting PI3K/AKT/mTOR pathway. J. Cell. Mol. Med. 2019, 23, 7525-7534. [CrossRef]

39. Peidl, A. A friend in knee: CCN3 may inhibit osteoarthritis progression. J. Cell. Commun. Signal. 2018, 12, 489-490. [CrossRef]

40. Hattori, T.; Müller, C.; Gebhard, S.; Bauer, E.; Pausch, F.; Schlund, B.; Bösl, M.R.; Hess, A.; Surmann-Schmitt, C.; Von Der Mark, H.; et al. SOX9 is a major negative regulator of cartilage vascularization, bone marrow formation and endochondral ossification. Development 2010, 137, 901-911. [CrossRef]

41. Tomita, N.; Hattori, T.; Itoh, S.; Aoyama, E.; Yao, M.; Yamashiro, T.; Takigawa, M. Cartilage-specific over-expression of CCN family member 2/connective tissue growth factor (CCN2/CTGF) stimulates insulin-like growth factor expression and bone growth. PLoS ONE 2013, 8, e59226. [CrossRef] [PubMed]

42. King, K.B.; Kimura, J.H. The establishment and characterization of an immortal cell line with a stable chondrocytic phenotype. J. Cell. Biochem. 2003, 89, 992-1004. [CrossRef] [PubMed]

43. Itahana, K.; Itahana, Y.; Dimri, G.P. Colorimetric detection of senescence-associated $\beta$ galactosidase. Methods. Mol. Biol. 2013, 965, 143-156. [CrossRef] [PubMed]

(C) 2020 by the authors. Licensee MDPI, Basel, Switzerland. This article is an open access article distributed under the terms and conditions of the Creative Commons Attribution (CC BY) license (http://creativecommons.org/licenses/by/4.0/). 